\title{
KAMPANYE ONLINE ANTI PORNOGRAFI: "PORNOGRAFI" UNTUK KALANGAN ANAK MUDA
}

\author{
Andreas James Darmawan; Dyah Gayatri Putri \\ Visual Communication Design, School of Design, BINUS University \\ Jln. K.H. Syahdan No. 9, Palmerah, Jakarta Barat 11480 \\ james.darmawan@binus.edu,dyah@binus.edu
}

\begin{abstract}
Nowadays, the internet technology is getting an opportunity to visit pornographic sites. Thus, more and more people have a dependency with a pornography site that is not easy to be released. Campaign against pornography "porNOgraphy" aims to raise awareness of young people to know the risks as well as providing a solution to escape from addiction to pornography. Both impact and solutions to the campaign message is packaged in audio-visual communication, so it is very persuasive in getting people to stay away from pornography and is expected to be easily understood by the public. Hope on the impact of this campaign is that people are interested in trying the suggestions in order to break away from addiction to pornography and form a strong intention and determination to be able to obtain a successful outcome.
\end{abstract}

Keywords: anti-pornography, Kobus character, audio visual media, online publication media

\begin{abstract}
ABSTRAK
Jaman sekarang, teknologi internet semakin membuka kesempatan untuk mengunjungi situs pornografi. Sehingga, semakin banyak orang memiliki ketergantungan dengan situs pornografi yang tidak mudah untuk dilepaskan. Kampanye anti pornografi "porNOgrafi" ini bertujuan untuk meningkatkan kesadaran kaula muda untuk mengetahui resiko sekaligus memberikan solusi untuk melepaskan diri dari kecanduan pornografi. Baik dampak maupun solusi pada pesan kampanye ini dikemas dalam komunikasi audio visual, sehingga sangat persuasif dalam mengajak masyarakat untuk menjauhi pornografi dan diharapkan mudah dimengerti oleh masyarakat. Harapan pada dampak kampanye ini adalah masyarakat tertarik untuk mencoba saran-saran guna melepaskan diri dari kecanduan pornografi dan membentuk tekad dan niat yang kuat untuk dapat memperoleh hasil yang sukses.
\end{abstract}

Kata kunci: anti-pornografi, karakter Kobus, media audio visual, media publikasi online 


\section{PENDAHULUAN}

Seiring dengan bertambah canggihnya teknologi informasi dan komunikasi terutama dalam internet, makin terbuka lebar pula celah untuk merambah ke wilayah pornografi. Sebagai akibatnya makin bertambah banyak jumlah orang yang mengakses ke situs pornografi dan akhirnya menjadi terikat. Keterikatan ini menjadi kecanduan yang tidak mudah dilepaskan. Kecanduan adalah kondisi ketergantungan pada sesuatu sehingga tidak dapat melangsungkan hidup secara efektif tanpa hal tersebut. Dengan kata lain, kecanduan pornografi akan membuat ketergantungan untuk terus mengkonsumsi, sebab jika tidak mengkonsumsi, akan muncul perasaan sulit untuk melakukan pekerjaan lain. Hal ini sangat berbahaya terutama bagi kawula muda, yang belum mengerti tanggung jawab dan komitmen dibalik seks yang ditawarkan pornografi.

Banyak yang mencoba untuk bernegosiasi dalam pornografi, sebenarnya baik dalam agama, medis maupun mental, pornografi dianggap merusak. Untuk itu perlu pemahaman yang jelas bahwa pornografi memiliki dampak negatif baik dari sisi spiritual, rasional, dan emosional. Secara mental, menurut Fanggidae (2006), pornografi membuat fantasi yang tidak wajar yang akan berpengaruh dalam tindakan nyata. Secara agama, menurut Lambert (2012) pornografi dianggap melecehkan nilai perkawinan yang suci. Secara medis, juga telah terbukti bahwa pornografi yang memicu masturbasi yang dapat menyebabkan gangguan syaraf yang memicu kemandulan (Hilton \& Watts 2011).

Sekarang seiring dengan perkembangan internet mobile, pornografi semakin mudah untuk diperoleh. Pornografi bisa diakses kapan dan di mana saja. Bahkan bagi sebagian kalangan tertentu, pornografi sudah dianggap lucu, wajar dan bahkan menyehatkan. Untuk itu target audience perlu diedukasi kembali bahwa pornografi itu merusak sehingga harus ditolak dan dihindari. Kontradiktif dan dilematis untuk menyampaikan fakta bahwa pornografi itu bisa merusak, karena perlu disampaikan secara konotatif, namun di sisi lain juga harus dapat diterima secara denotatif. Perlu adanya sebuah gerakan Kampanye Anti Pornografi yang persuasif, atraktif, dan edukatif.

Kampanye ini sangat diperlukan berbagai kalangan dan umur, namun dalam menyampaikan komunikasi yang lebih spesifik, perlu adanya batas ruang lingkup. Ruang lingkup untuk kampanye kali ini dapat melalui demografi dan geografi target audience-nya. Ruang lingkup akan dipilih berdasarkan usia yang berkaitan dengan tahapan biologis (baik secara intelektual maupun hormonal) dan lokasi kampanye yang akan menyesuaikan alat/items kampanye.

\section{METODE}

Penulis menggunakan metode kualitatif baik secara literatur, maupun yang langsung secara observasi terhadap perilaku ramaja dalam melakukan aktivitas online di warnet dan melakukan wawancara secara online (chatting) pada remaja yang memiliki kebiasaan online dalam melakukan tugas maupun mengisi waktu luang. Metode kualitatif ini dilakukan penulis dengan pendekatan personal, baik biodata narasumber dan hasil survei dirahasiakan, guna mendapatkan masukan yang jujur. Penulis memperoleh hasil yang dapat menjadi acuan penelitian yang berbasis komunikasi visual. Hasil survei dan wawancara ini meliputi dari bagaimana cara mengkomunikasikan pesan, siapa yang menjadi penyampai pesan dan media apa yang dipilih untuk menyampaikan pesan tersebut.

Selain itu, berdasarkan studi literatur, ada pula cara yang penting dalam penyampaian pesan adalah sifat ajakan yang mudah diingat, sehingga penulis melakukan pendekatan komunikasi verbal yang sederhana, yaitu mengemas pesan menjadi strategi tiga-tiga (three on three); yaitu tiga dampak dari kecanduan pornografi (termasuk pertimbangan perubahan pada perilaku, dampak pada kehidupan pernikahan kelak bagi target, serta dampak kesehatan fisik yang merusak vitalitas dan kesuburan) serta tiga cara penanggulangan atau melepaskan diri dari kecanduan pornografi tersebut. Diharapkan 
melalui pesan verbal yang sederhana ini, pesan dapat ditangkap dengan cepat dan mudah diingat para anak muda (sebagai target), sehingga menjadi dasar ajakan logis untuk turut memerangi kecanduan pornografi ini (mulai dari metode pendekatan diri pada Tuhan, mengubah kebiasaan dan aktivitas menjadi lebih positif, serta ajakan untuk mengubah pola online).

Tabel 1 Strategi Verbal Three On Three

(Darmawan, 2010)

\begin{tabular}{lll}
\hline Pesan Kampanye & \multicolumn{1}{c}{ Dampak Kecanduan } & \multicolumn{1}{c}{ Cara Penangulangan } \\
\hline Pesan pertama & Melahirkan prilaku yang mesum & Mendekatkan diri pada Tuhan \\
Pesan kedua & Menggoyahkan rumah tangga & Mengajak beraktivitas positif \\
Pesan ketiga & Merusak vitalitas dan kesuburan & Mengubah pola pencarian situs \\
\hline
\end{tabular}

Untuk kampanye Anti Pornografi ini sendiri, memang ditujukan kepada kaum muda dan tidak memiliki dana kampanye yang besar. Untuk itu metode yang dipilih untuk melaksanakan kampanye ini adalah media online, namun tetap didukung oleh media ambience. Ide dari media online ini sebenarnya adalah membuat sebuah komunitas yang memiliki. Ada tiga penerapan ide kampanye ini, pertama, membuat sebuah media utama yaitu media yang menceritakan tentang dampak pornografi dan masturbasi yang mengganggu pernikahan. Media utama ini akan berbentuk animasi film pendek, dan mengambil gaya visual ilustrasi. Hasilnya akan dipublish dalam website video publisher yang online. Kedua, media cetak pendukung yaitu media yang menjadi teaser yang ambience bagi media utama, yang bersifat memancing rasa ingin tahu dan diarahkan untuk melihat kelanjutannya di media utama online. Media cetak sebagai media pendukung ini akan diterapkan secara bellow the line, baik yang sifatnya ditayangkan maupun dibagikan. Dampak yang ingin diperoleh; pada website tersedia like button dan kolom testimonial. Semua testimonial yang membangun akan tetap ditayangkan sekaligus menghimpun komunitas.

\section{HASIL DAN PEMBAHASAN}

Penulis juga menemukan perlunya logo yang menarik untuk menjadi identitas utama dari gerakan kampanye ini. Dengan demikian penulis merancang logo kampanye dengan pendekatan permainan verbal pada logotype kampanye dengan memberikan penekanan pada kata NO pada pornografi. Selain itu penulis juga melakukan tambahan penekanan dengan merancang logogram yang berupa gambar stilasi telapak tangan yang menjadi penekanan visual yang memiliki ukuran dan warna yang menonjol (merah).

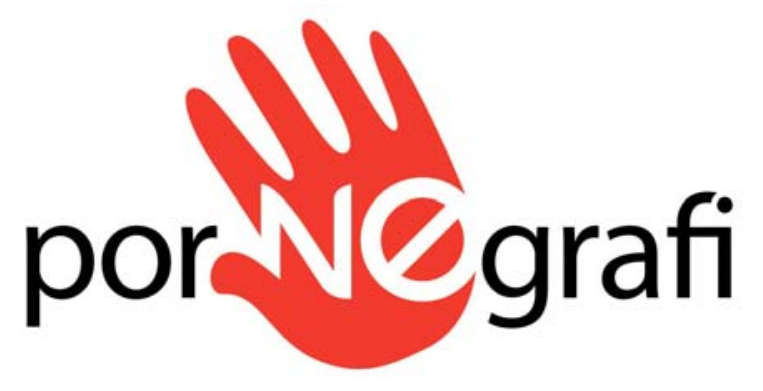

Gambar 1 Logo Kampanye Anti Pornografi

(Darmawan, 2010) 
Selain logo, penulis juga menemukan bahwa beberapa tokoh fiktif perlu menjadi komunikator kampanye ini, hal ini seiring pula dengan kegiatan penulis yang aktif mengisi rubrik komik mingguan bernama Kobus, di mana telah tercipta beberapa karakter yang dapat mendukung kampanye ini. Dari beberapa karakter yang ada, penulis memilih tiga karakter pula yang akan bermain pada media utama kampanye Anti Pornografi ini, yaitu Kobus sebagai pemeran utama, Titin sebagai pacar Kobus, dan Dombi sebagai sahabat baik Kobus.

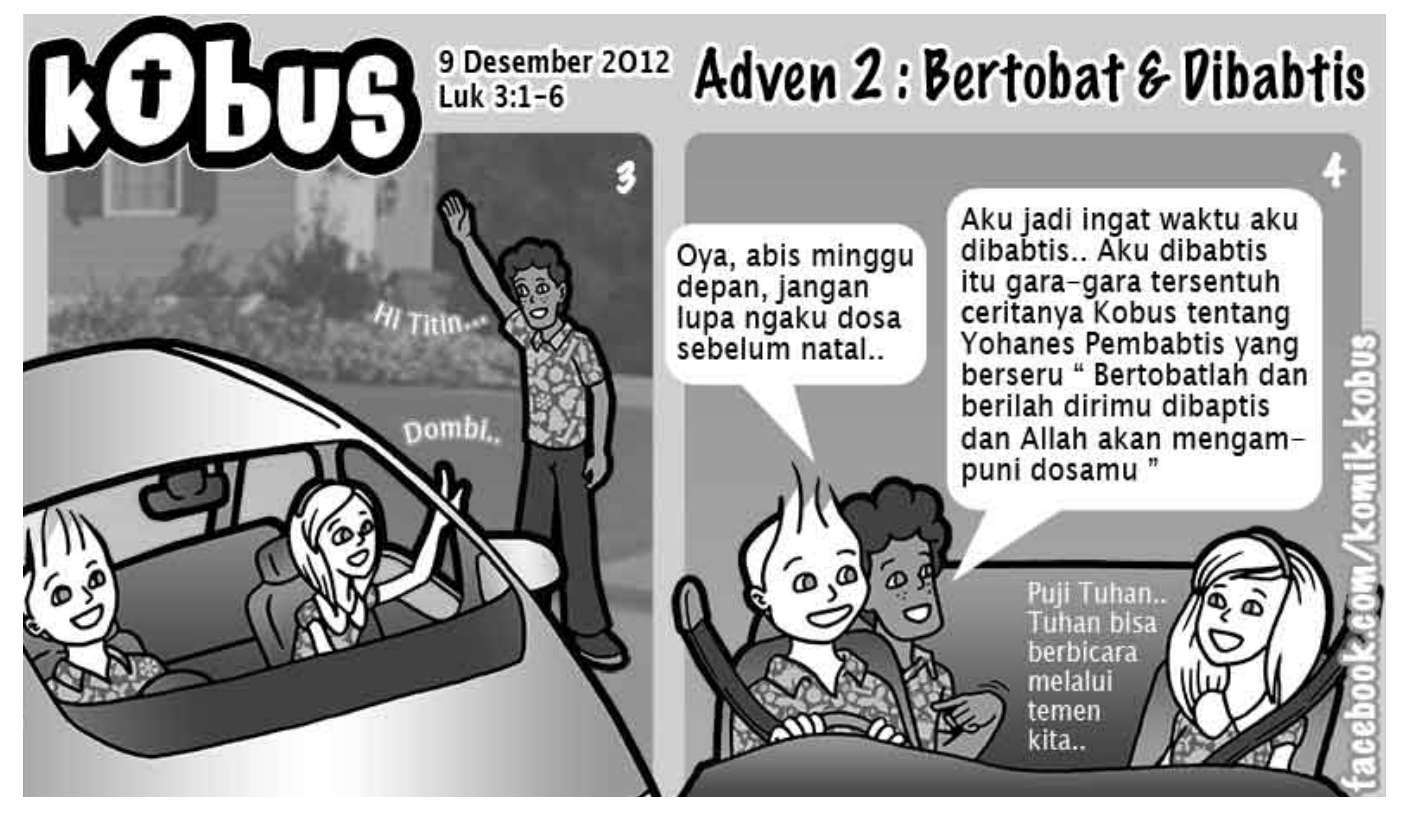

Gambar 2 Contoh Komik Mingguan Kobus

(Darmawan, 2010)

Setelah ditemukan logo dan karakter, penulis juga menetapkan strategi komunikasi yang menggunakan media-media yang berdekatan dengan target. Dalam hal ini, penulis memilih jenis media elektronik (gadget) yang online. Untuk itu, penulis membuat media utama kampanye berupa media audio visual. Sebuah media yang persuasif dari sisi visual, attraktif media audio visual berupa animasi film pendek, dan edukatif pesan yang mudah serta sederhana.

Awal pembuatan animasi film pendek ini sendiri dilakukan penulis dengan proses sketsa. Sketsa dilakukan untuk menentukan letak visual dengan angle camera yang paling tepat. Penilaian tepat di sini adalah mencari unsur visual dengan sensasi dramatis dalam penyampaian pesan.Berdasarkan sketsa inilah penulis dapat mempertimbangkan efisiensi pembuatan gambar dan gerakan animasi dengan penyampaian pesan dengan pendekatan visual yang sederhana, mudah dicerna, dan terlihat sangat menarik. 

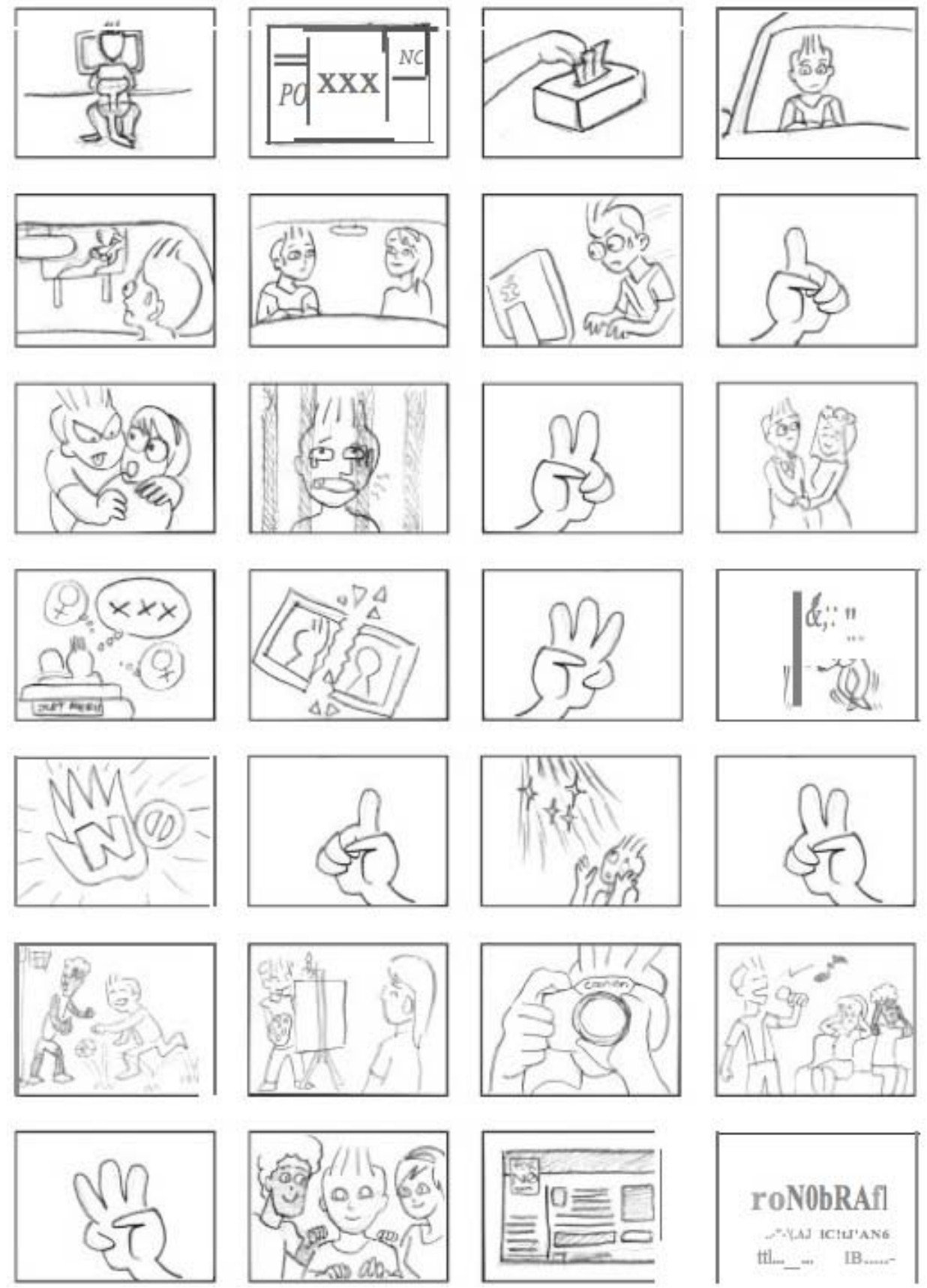

Gambar 3 Sketsa Animasi Film Pendek Anti Pornografi (Darmawan, 2010)

Setelah proses sketsa, penulis melanjutkan proses yang selanjutnya yaitu masuk dalam pembuatan visual menggunakan sistem ilustrasi komputer berbasis vektor grafik. Menurut Darmawan (2010) sistem ini menjadi sebuah gaya visual yang modern, dengan visualisasi fill and outline, dan ditambah gradasi sederhana untuk pembentukan volume visual. 


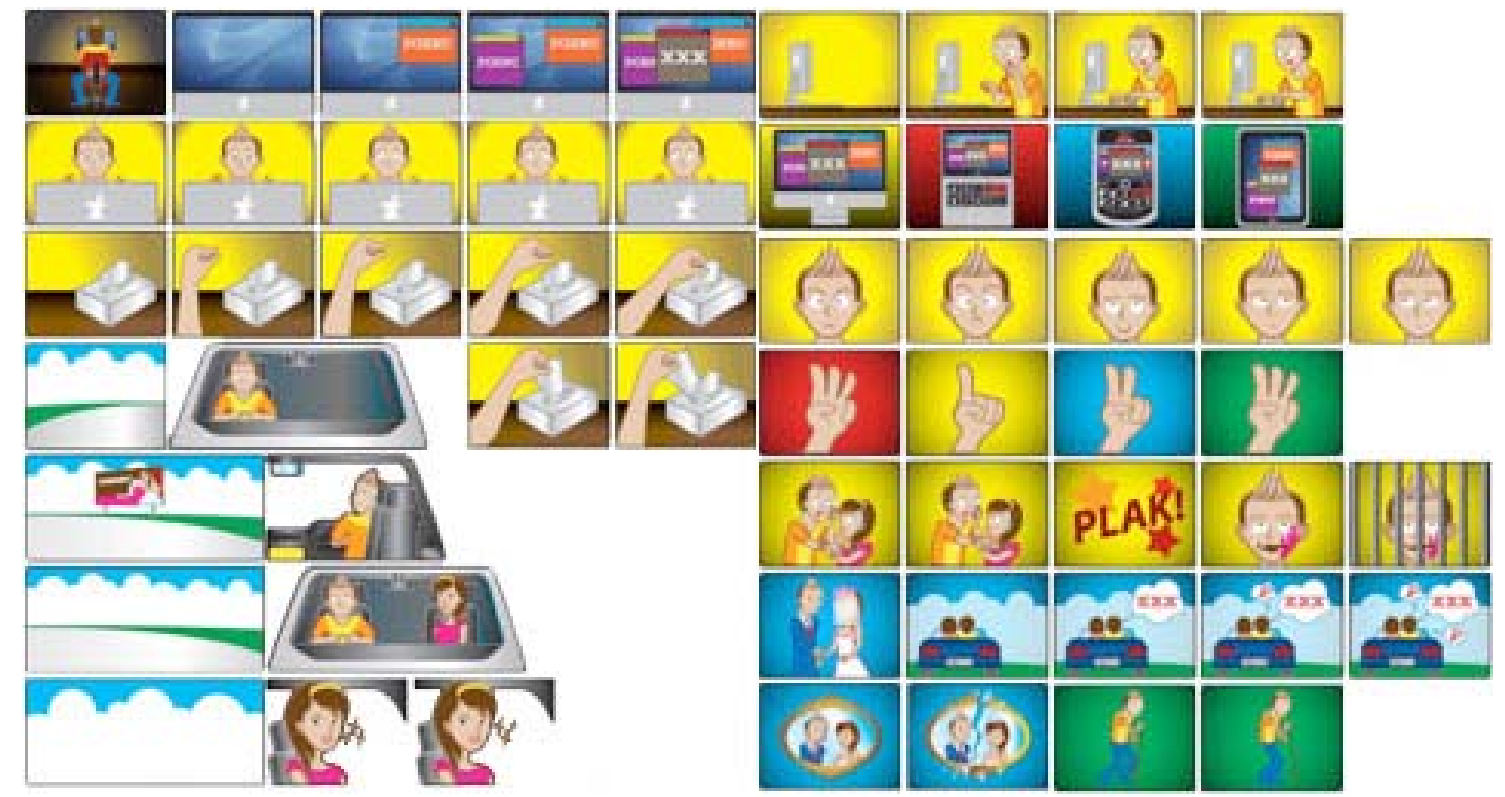

Gambar 4 Vektorisasi Bahan Animasi Film Pendek Anti Pornografi

(Darmawan, 2010)

Hasil animasi ini dapat dilihat pada Youtube dengan melakukan pencarian "Anti Pornografi" pada situs broadcast online www.youtube.com yang dipilih penulis sebagai media publikasi utama kampanye. Dasar pemilihan media ini adalah penggunaan yang tidak dikenakan biaya, laporan statistik yang lengkap, dan popularitas situs dalam kategori media audio visual online. Diharapkan melalui situs ini, media utama kampanye dapat tersebar luas dan cepat.

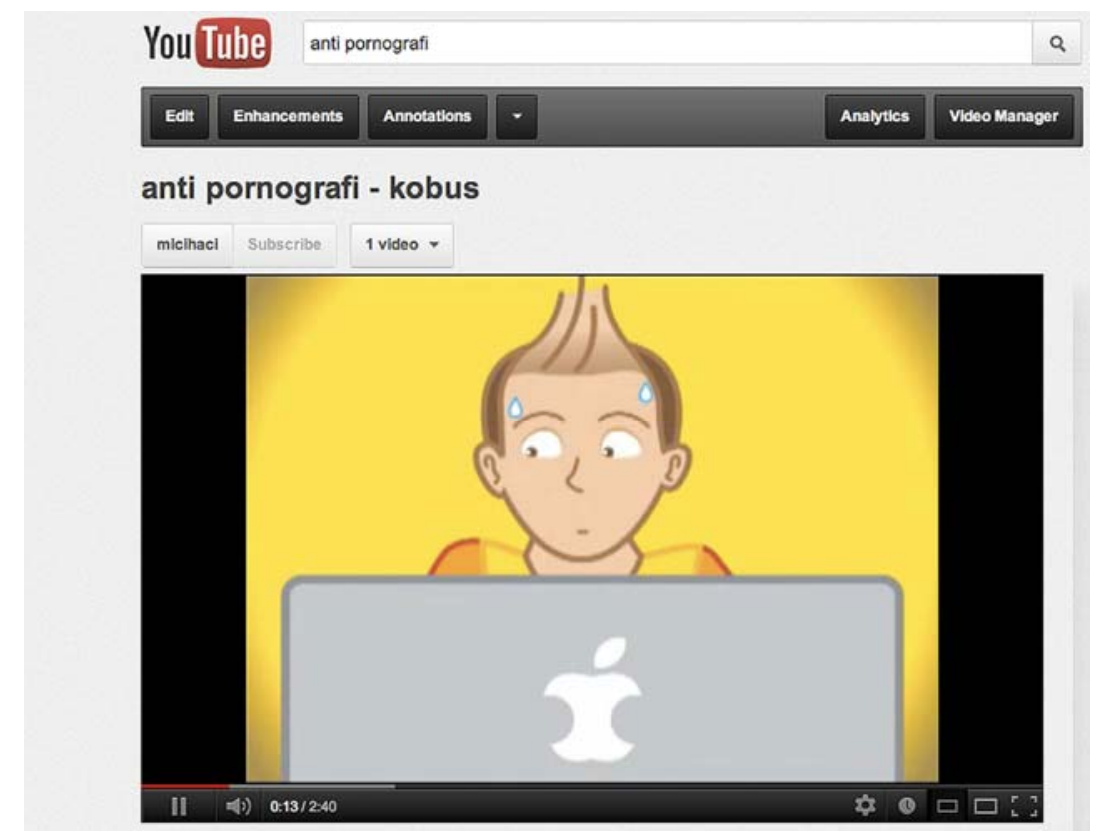

Gambar 5 Animasi Film Pendek Anti Pornografi Pada Youtube (Darmawan, 2010) 
Selanjutnya untuk teaser, sengaja dilakukan pendekatan ambience.Visual juga sengaja dibuat berupa visualisasi media-media elektronik seperti handphone Blackberry, pad dari Android, dan laptop dari Apple. Hal ini dilakukan dengan pertimbangan kedekatan benda-benda elektronik tersebut dengan target audience. Diharapkan teaser dapat memancing rasa ingin tahu dan diarahkan untuk melihat audio visual sebagai media utama penyampaian pesan secara online.

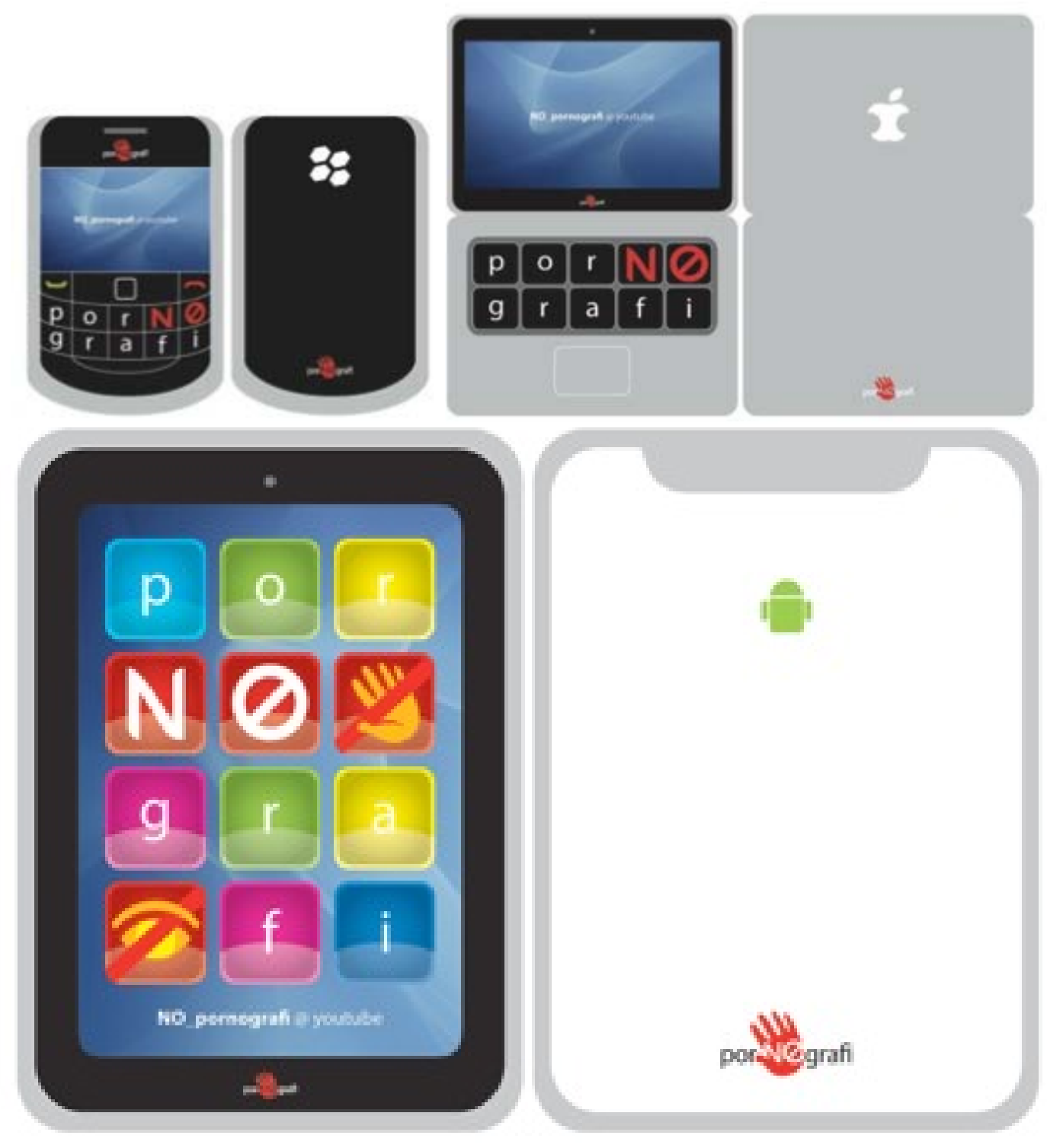

Gambar 6 Teaser Kampanye Anti Pornografi

(Darmawan, 2010)

Penulis juga membuat lembar aktivitas kecil berupa papertoy yang dapat dibentuk menjadi komputer. Hal ini dilakukan untuk pengingat (reminder) bagi target yang dituju. Dengan keunikan papertoy ini, diharapkan reminder kampanye Anti Pornografi ini tetap dikoleksi dan menjadi daya tarik yang unik pada meja atau tempat benda ini dipajang. 


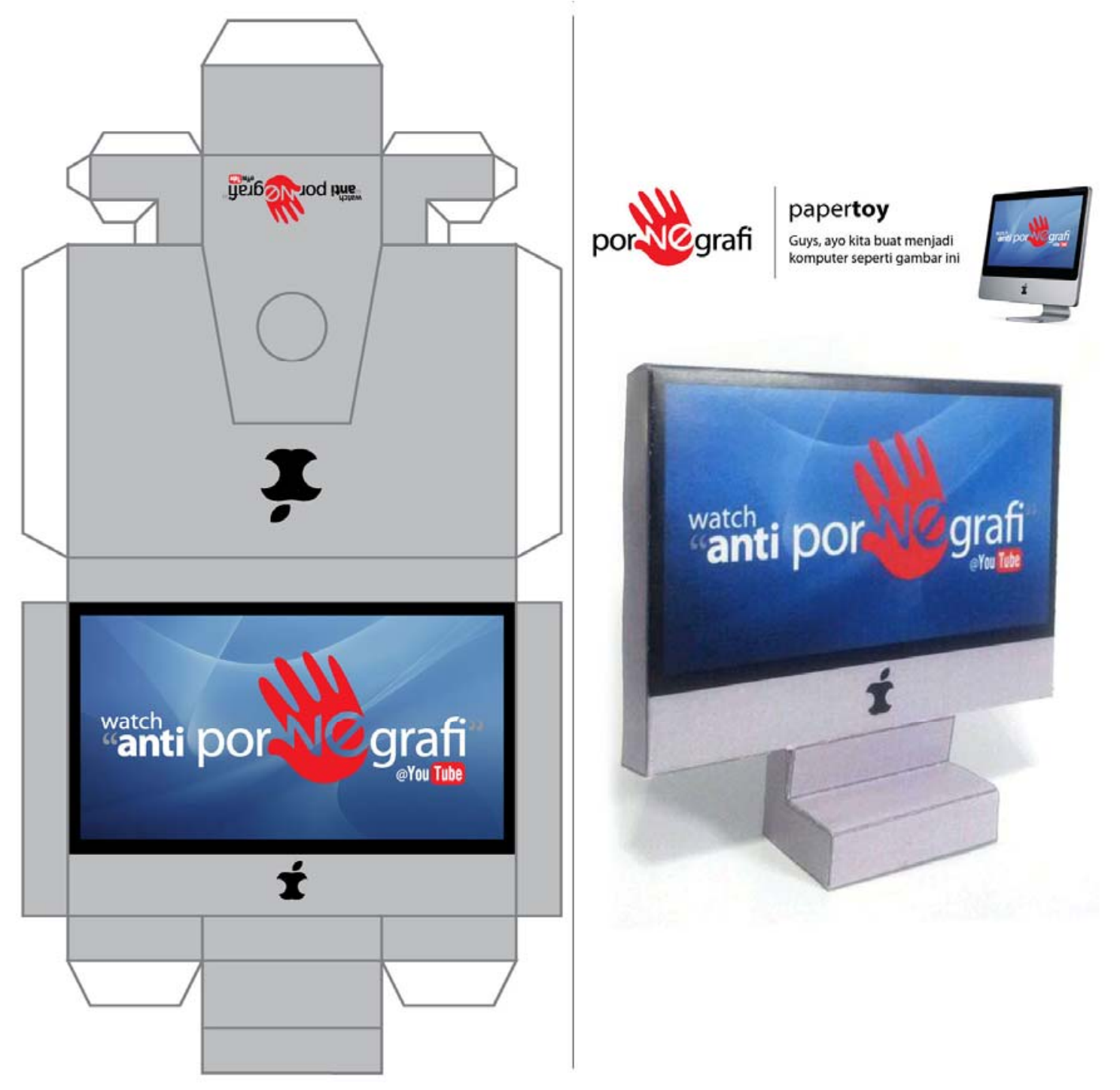

Gambar 7 Reminder Kampanye Anti Pornografi

(Darmawan, 2010)

Selain dari jenis reminder yang unik, penulis juga membuat reminder lain yang lebih sederhana berupa postcard yang diharapkan dapat membantu penyebaran kampanye karena fungsional.Selain itu itu penulis juga memiliki media yang berdimensi lebih besar yaitu poster, untuk menjadikannya unik, poster dibuat dapat dibolak-balik yang memaparkan dua sisi yang positif dan negatif. 


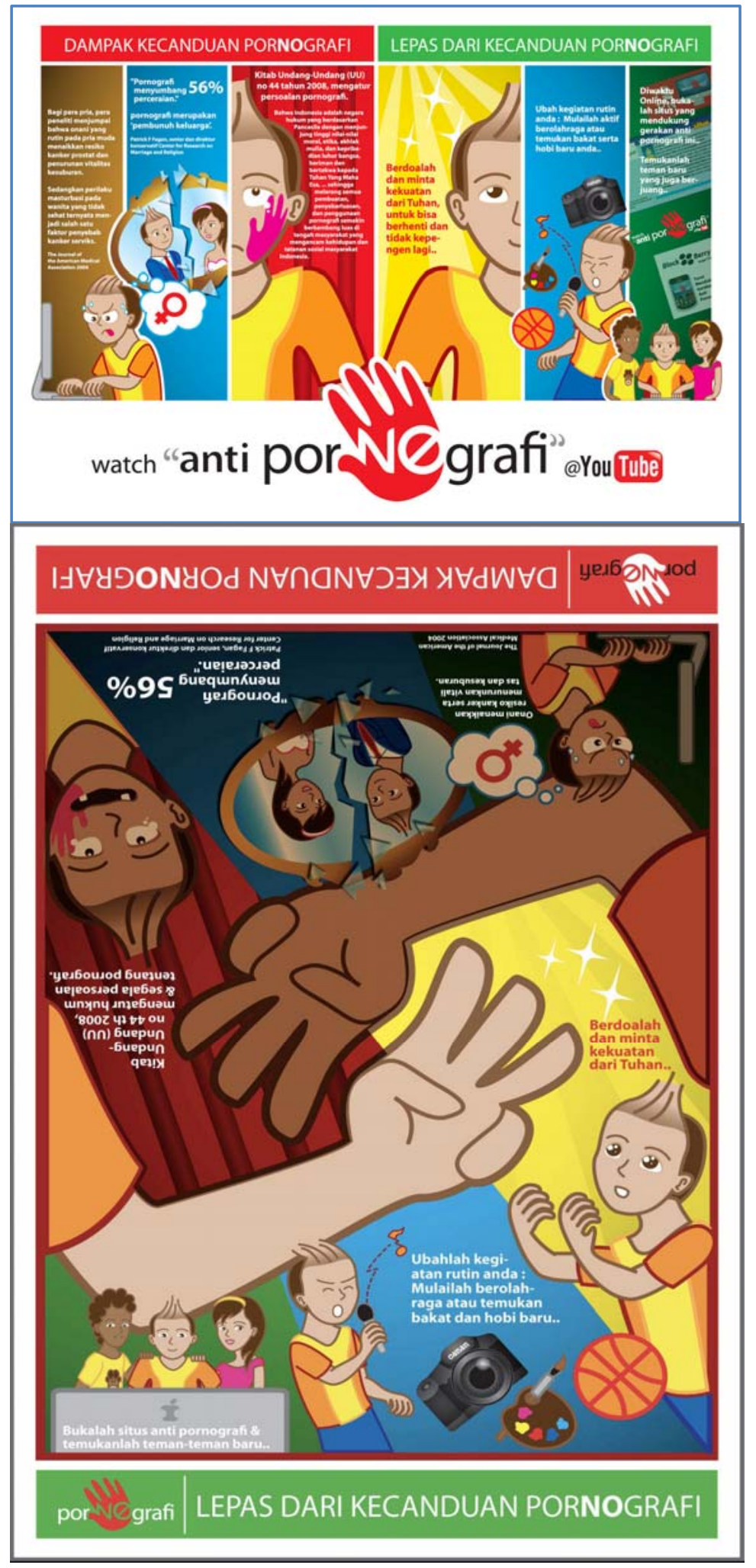

Gambar 8 Poscard dan Poster Kampanye Anti Pornografi (Darmawan, 2010) 


\section{SIMPULAN}

Kampanye anti pornografi "porNOgrafi” ini dinilai sangat penting dalam meningkatkan kesadaran kawula muda untuk mengetahui resiko dampak dari kecanduan pornografi. Kawula muda yang selama ini menganggap wajar bahkan lucu mengenai prilaku menyimpang ini, diharapkan dapat berpikir dua kali setelah melihat / mengetahui inti pesan dari kampanye ini. Selain itu, kampanye anti pornografi ini juga memberikan solusi untuk melepaskan diri dari kecanduan pornografi. Solusi ini disampaikan secara gamblang, sehingga diharapkan mudah dimengerti dan persuasif dalam mengajak kalayak target. Kalayak target sangat diharapkan untuk masuk dalam tahap mencoba saran-saran untuk melepaskan diri dari kecanduan ini. Semoga kebulatan tekat dan niat yang kuat dapat memperoleh hasil yang sukses. Kampanye ini sebaiknya didukung oleh pemerintah maupun masyarakat. Hal ini merupakan ajakan yang berdasarkan sebuah tatanan norma dan etika khususnya bagi pembentukan moral dan mental kawula muda generasi penerus bangsa. Terlepas dari latar belakang agama, ras, dan suku, kampanye ini diharapkan untuk memperoleh dukungan yang besar untuk menentukan langkah pendekatan anti pornografi selanjutnya.

Kampanye Anti Pornografi ini dinilai sangat penting dalam meningkatkan kesadaran kaula muda untuk mengetahui resiko dampak dari kecanduan pornografi. Kawula muda yang selama ini menganggap wajar bahkan lucu mengenai perilaku menyimpang ini, diharapkan dapat berpikir dua kali setelah meihat / mengetahui inti pesan dari kampanye ini. Selain itu, kampanye anti pornografi ini juga memberikan solusi untuk melepaskan diri dari kecanduan pornografi. Solusi ini disampaikan secara gamblang, sehingga diharapkan mudah dimengerti dan persuasif dalam mengajak masyarakat. masyarakat juga diajak untuk mencoba saran-saran untuk melepaskan diri dari kecanduan ini sehingga terbentuk kebulatan tekat dan niat yang kuat.

\section{DAFTAR PUSTAKA}

Darmawan, J. (2010). Proses Kerja Komputer yang dapat Mengoptimalkan Hasil Komunikasi Visual secara Efisien. Jurnal Humaniora, 1(1), 122-134. ISBN:2087-1236.

Fanggidae, E. (2006). Pornografi di Media Massa. Jakarta: Eukalyptus.

Hilton, D. L., \& Watts, C. (2011). Pornography addiction: A neuroscience perspective. Surgical Neurology International. San Antonio: Medknow Publications.

Lambert, H. (2012). The Problem of Pornography: Why It's Wrong and How to Help. The Journal for Biblical Manhood And Womanhood, 17(2). ISSN: 1544-5143. 